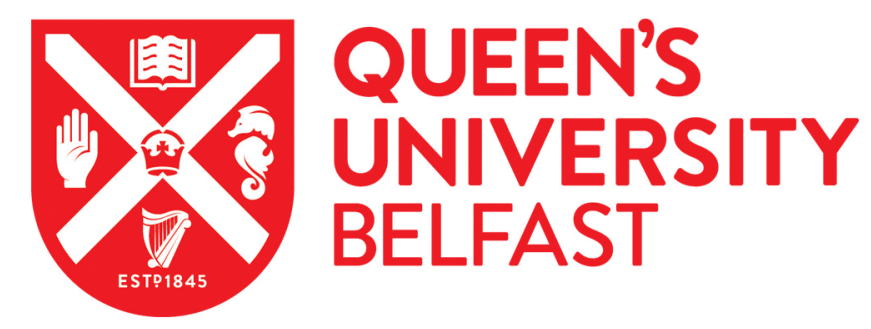

\title{
Brazil's Non-indifference: a case for a feminist diplomatic agenda or geopolitics as usual?
}

Rossone de Paula, F. (2019). Brazil's Non-indifference: a case for a feminist diplomatic agenda or geopolitics as usual? International Feminist Journal of Politics, 21(1), 47-66. https://doi.org/10.1080/14616742.2018.1542282

\author{
Published in: \\ International Feminist Journal of Politics
}

Document Version:

Peer reviewed version

Queen's University Belfast - Research Portal:

Link to publication record in Queen's University Belfast Research Portal

Publisher rights

(C) 2019 Informa UK Limited, trading as Taylor \& Francis Group.

This work is made available online in accordance with the publisher's policies. Please refer to any applicable terms of use of the publisher.

\section{General rights}

Copyright for the publications made accessible via the Queen's University Belfast Research Portal is retained by the author(s) and / or other copyright owners and it is a condition of accessing these publications that users recognise and abide by the legal requirements associated with these rights.

Take down policy

The Research Portal is Queen's institutional repository that provides access to Queen's research output. Every effort has been made to ensure that content in the Research Portal does not infringe any person's rights, or applicable UK laws. If you discover content in the Research Portal that you believe breaches copyright or violates any law, please contact openaccess@qub.ac.uk. 
BRAZIL'S NON-INDIFFERENCE: A CASE FOR A FEMINIST DIPLOMATIC AGENDA OR GEOPOLITICS AS USUAL? 
At the beginning of the twenty-first century, Brazil took advantage of its economic and political privileged position to challenge global normative structures. In 2004, the concept of 'non-indifference' was integrated into the Brazilian vocabulary of foreign policy, justifying and legitimating the country's acceptance of the invitation to command the MINUSTAH. On the one hand, non-indifference can be read as a discursive maneuver that enabled Brazil to accommodate its non-interventionist agenda to an old geopolitical game, given the pressure imposed upon 'global players' to respond effectively and assertively to threats to international peace and security. On the other hand, the 'Brazilian way' could also be seen as an alternative to a highly masculinizing geopolitical approach to international security. This paper explores possible limitations, tensions and/or opportunities that emerge from the encounter between a feminist diplomatic agenda and a masculinizing ordering of the international space. It does so by contrasting Brazil's ambition for a permanent seat at the United Nations Security Council (UNSC), the club of powerful states, with Brazil's diplomatic and military performance during the UN Stabilization Mission in Haiti (MINUSTAH), widely evaluated as a success due to characteristics such as solidarity, generosity, flexibility, and the 'warm conviviality' of Brazilian culture.

Brazilian diplomacy - Non-Indifference - MINUSTAH - International Security Feminist Geopolitics 
In 2005, Luis Inácio Lula da Silva, the president of Brazil from 2003 to 2010, highlighted the country's role in the configuration of a new political, economic, and commercial geography of the world (Da Silva 2005, 4). According to Celso Amorim (2010c), Brazilian former minister of foreign affairs, "countries like Brazil, China, India, South Africa and a few others [were] the 'new kids on the block' among global players that shape international relations [...]. Global decisions [could] no longer be made without listening to their "voices"'.

Amorim (2010a) stated that "Brazil favor[ed] a non-selective, objective and multilateral treatment of human rights, without politicization or bias, in which everyone - the rich and the poor, the powerful and the weak - is subject to the same scrutiny". In order to build new international governance, Brazil diversified its partners and aligned with other emerging economies in coalitions such as BRICS, IBSA, and G20 ${ }^{1}$ (Mesquita \& Medeiros 2016, 405). Solidarity, in the form of SouthSouth technical and humanitarian assistance, became a significant concept in Lula's diplomacy (Faria and Paradis 2013).

The first decade of the twenty-first century was marked by an increasing decentralization of decision-making power in multilateral institutions, which opened up the space for a more active role of emerging powers in the making of world politics. The new Brazilian foreign policy included the aim for "continental solidarity" and the construction of "a more equitable and democratic international order" (Da Silva 2005, 2). The Brazilian diplomatic activity of this period reflected the new goals of foreign policy (Mesquita \& Medeiros 2016; Visentini 2011). For Lula, Brazil needed to stop thinking of itself as a third-world country that depended on the United States and the European Union to decide on what it was allowed or not to do (Da Silva 2005, 11). In order to do that, it needed to strengthen its voice in 
multilateral institutions, such as the UN, considered an important instrument of diplomacy (see Hovet 1963).

This paper examines Brazil's effort to be part of the club of powerful states at the beginning of the twenty-first century, focusing on the tensions between particular diplomatic discourses and practices that characterized the first ten years of the leftist government in Brazil (2003-2013) ${ }^{2}$ and the country's efforts to meet criteria for a distinguished position on the global stage. More specifically, this paper contrasts Brazil's ambition for a permanent seat at the United Nations Security Council (UNSC) with Brazil's diplomatic and military performance in the UN Stabilization Mission in Haiti (MINUSTAH). I argue that this tension reveals that the process through which states pursue a 'significant position' in international politics is fundamentally gendered, limiting the space for the implementation of feminist diplomatic agendas. While Brazilian representatives' important role at the mission has been recognized as part of the country's effort to demonstrate readiness to assume greater responsibility in the international security arena, the 'Brazilian way' of contributing to peace operations has been interpreted as a potential obstacle to the pursuit of a more significant position on the global stage, to the extent that it is associated with south-south solidarity, exceptionalism (Kenkel 2013b, 350-351) and the promotion of a new geography for cooperation that favors less hierarchical relationships. The non-recognition of Brazil's diplomatic emphasis on south-south cooperation and solidarity with other states from the global South as an asset in its pursuit of a permanent seat at the UNSC can be revealing of the lack of space states find to the performance of an alternative subjectivity to the dysfunctional 'masculine' roles they are called to assume in order to have a voice in world politics (Hoffman 2001; Hooper 2001; Conway 2008). My analysis consists of analyzing discourses 
about Brazil's successes and failures in both contexts (MINUSTAH and its pledge for a permanent position at the UNSC) in order to reveal the hierarchical and gendered nature of rankings, qualities and values embedded in the distribution of positions, status and subjectivities in global politics. By doing this, we may be able to tackle the structural limitations and obstacles for the recognition of broader feminist agendas in political spaces.

In the first section, I lay out the conceptual framework informing my analysis. Next, I examine the shift in Brazil's foreign policy discourses and diplomatic agenda from non-intervention to non-indifference in the context of its emergence as a stronger player in multilateral fora. In the third part, I analyze Brazil's participation in the MINUSTAH, highlighting the uniqueness of Brazil's approach and practices regarding international security, as well as Brazil's contribution of a new conceptual framework for international intervention. Finally, I discuss the tension between Brazil's ambition for a greater space for governance as a global player and its nontraditional, perhaps more diplomatic, approach to international security. In conclusion, I suggest that feminist, and possibly 'feminine', geopolitical imaginaries are necessary before feminist diplomatic agendas can be translated into significant and influential status in international politics.

\section{A SPACE FOR A 'FEMINIST' DIPLOMATIC AGENDA?}

In this paper, a 'feminist' agenda or policy is broadly defined as one that questions the way in which "seemingly neutral concepts [...] are rendered in highly masculinized ways, such that they come to denote control, domination, and sameness" (Dixon 2016, 43; Hutchings 2008). I suggest that agendas and policies that challenge 
the strict separation between 'self' and 'other', while emphasizing the horizontality of this relationship through notions of solidarity and shared 'incompleteness' could be classified as feminist. It could also be said that my analysis lies at the intersection between feminist and postcolonial accounts of hierarchies and inequalities that plagues world politics. As Geeta Chowdhry and Sheila Nair explain, a postcolonial attentiveness to the imbrication of race, class and gender "constitutes an effort to generate an alternative critique of global power hierarchies and relations" (Chowdhry \& Nair 2002, 2).

Hyndman's (2004) broad and inclusive conceptualization of 'feminist' as one that characterizes "political interventions that address the asymmetrical and often violent relationships among people based on real or perceived social and cultural differences" (Hyndman 2004, 309) is useful, given my goal of discussing the space for the 'feminine' in world politics. As a contribution to feminist institutional and geopolitical scholarship, this study is not focused on the inclusion of women in the political map, but to the gendered nature of institutions (Aggestam \& Towns 2018, 12-14) and the dynamics of world politics that continually reinforce and produce gender inequalities. Lisa Ann Richey's analysis of the Danish feminist foreign policy is an example of this kind of investigation, in which she asserts that "gender [...can] provide an arena for the international constitution of domestically 'feminist' policies" (Richey 2001, 178), but to the extent that the promotion of development, for instance, implies an explicit separation between 'donor' and 'receiver', in which 'receiver' is constructed as an 'other' who is in 'need of change', we could argue that "the very nature of development aid is gendered" (Richey 2001, 178).

Diplomacy is one of the apparatuses a government has available to the pursuit of its established foreign policy goals. It can also be broadly defined as "a claim to 
represent a given polity to the outside world" (Sending et at. 2015, 5). For Sending et al. (2015), diplomacy "helps reproduce the state as the naturalized political arena for the generation of meaning and belonging" (7). By seeing diplomacy "as an infrastructure for the making of world politics", and focusing on Brazil's efforts to represent itself as an aspiring global player fighting a hierarchical order, one may observe "neglected causal pathways through which particular orders are continually reproduced" (Sending et al. 2015, 7). In contrast to Sweden or Canada ${ }^{3}$, Brazil has never claimed to have a feminist foreign policy or a feminist diplomatic agenda. Brazil's stated goals of foreign policy, such as universal solidarity, south-south cooperation, and the reform of decision-making structures of multilateral institutions, were pursued by what has been called an 'active and affirmative' diplomacy (Visentini 2011). Nevertheless, Brazil's 'active and affirmative' diplomacy can be relevant to feminist analyses to the degree that feminists are invested in looking at "the prevailing power relations and discursive practices that position groups of people in hierarchical relations to others" (Hyndman 2004, 309).

Diplomatic activity, the venue through which a country represents itself and is represented to the world, is a performative act, defined as the "signification and action of discourse" (Butler 1997, 44). Speeches, decisions, encounters, meetings, campaigns, promises, agreements, and disagreements can "produce effects that are both theoretical and material, symbolic and pragmatic" (Richey 2001, 179), but they are also recognized within certain limits of intelligibility.

Mesquita and Medeiros (2016) describe four stages through which a State may reshape its role in the world: (a) Breakdown of consensus on identity commitments; (b) Critical examination of old ideas about oneself and the Other, in order to formulate a new theory, better adapted to the situation experienced; (c) Acting to 
change the identities and interests of other agents; and (d) Feedback from the Other (389-390). In the leap from the third to the fourth stage, "the legitimation process takes place [...], when foreign policy is interpreted by Others, whose feedback will determine whether or not this new identity is accepted" (Mesquita \& Medeiros 2016, 391). This study demostrates that "intelligibility of a new identity depends on the peers with which it interacts and their social identities $-\mathrm{a}$ factor often beyond the control of the State attempting to redefine itself" (Mesquita \& Medeiros 2016, 416). For this reason, what is at stake here is the extent to which Brazil has been able to position and represent itself differently while contesting the hierarchization of difference through the encounter with the 'other'. Any account of feminist diplomacy concerned with the obstacles to the implementation and validity of feminist agendas should also take into account the current geography of politics, of intelligibility, and the opportunities that open up to transformation. This analysis suggests that feminist diplomatic discourses and practices should find space within a more permissive feminist geopolitics.

Some scholars emphasize the unlikelihood of a feminist geopolitics due to an ontological and epistemological incompatibility between these two sub-disciplines (Staeheli 2001). While feminists are concerned with moving bodies on the map (see Kofman 1996; Pettman 1996; Staeheli et al. 2004), geopolitics has been traditionally sustained upon masculinist reasoning (Dowler \& Sharp 2001, 165). Koopman (2011) clarifies that "if hegemonic geopolitics is Big Men moving pieces on the board, [...] feminist geopolitics sees both the players and the pieces on the board, the relationship between them, and the ways the pieces might move themselves" (282). The coming together of 'Feminist' and 'geopolitics' become a possibility when we have the courage to face the 'abstract geopolitical' as feminists. This does not mean to deny the 
suffering and subjugation happening on the level of bodies, but to avoid a 'retreat to place' and to the 'everyday' (Massey 2005, 5-6) in opposition to 'space' and the 'Big Men's' maps.

Ó Tuathail (1996) reminds us that critical geopolitics is only "a small part of a much larger rainbow struggle to decolonize our inherited geo-graphical imagination so that other geo-graphings and other worlds might be possible" (256). Feminist geopolitics then helps us to ask questions such as what are the obstacles to the making of a world in which solidarity can be ranked as a strong quality of those who seek recognition, voice and power?

\section{BRAZIL IS INVITED TO BE TOUGH}

Brazil has been an active and constant presence at the United Nations since its foundation, having contributed to the creation of the UN Charter and participated in the preparatory work prior to the first session of the General Assembly. Brazil has even been considered one of the 'six powers of the world' by the Brazilian delegation in the context of its nomination as a non-permanent member for a mandate of two years in 1946 (see Moura 2013; Corrêa 2013). Nevertheless, the country has never been widely recognized as a protagonist in decision-making processes concerning international security.

Evaluating the performance of Brazil from 2003 to 2010, Celso Amorim asserted that Brazil was "a country with greater responsibilities and an increasingly central role in the decisions that affect the destiny of the planet" (Amorim 2010b). In this context, extending Brazil's participation at the UNSC emerged as a crucial issue in Brazil's foreign policy agenda (Amorim 2005). In 2004, Brazil formally joined a 
coalition, the G4, with Japan, India, and Germany. The G4 presented a document (A/59/L.64) to the General Assembly, cosponsored by another 23 states, in which they propose an increase of the number of member states of the UN Security Council to 25 , with an additional 6 permanent members and 4 non-permanent members. The G4 claims that the power structure of the UNSC does not reflect the current geopolitical configuration of the world. Even though the number of member states of the United Nations has increased from 51 to 193 since 1945, there was only an increase in the number of non-permanent members from 6 to 10 in 1965 (Weiss 2003, 147).

'Legitimacy' and 'representativeness' have been invoked as good reasons for the redistribution of power at the UNSC (G4 2012), but there is little agreement on what could constitute sufficient reasons for a reform of the organ or what criteria should be used to judge the candidates (McDonald \& Patrick 2010, vi). Chapter V, Article 23 of the UN Charter, about the election of members, is unclear about "equitable geographic distribution":

the General Assembly shall elect ten other Members of the United Nations to be non-permanent members of the Security Council, due regard being specially paid, in the first instance to the contribution of Members of the United Nations to the maintenance of international peace and security and to the other purposes of the Organization, and also to equitable geographical distribution (UN Charter).

Geographical representation has been contested as a criterion for the selection of new permanent members. In a special report about the UNSC enlargement and the United States' interests, McDonald and Patrick (2010) affirm that the candidacies of emerging powers such as Brazil or India should be "weighed not on their role as regional leaders, but on their ability to help safeguard international peace" (7). According to them, the "primary consideration for permanent membership should be 
power - the ability and willingness to deploy it in the service of global security" (McDonald \& Patrick 2010, 9).

Representatives of Brazil understood that they could not cogently and legally convince the other permanent members of the necessity to expand the UNSC solely on the basis of geographic representation or the position of the country in the global economy. Instead, Brazil would have to demonstrate to be able to contribute more actively and assertively to the safeguarding of international peace. In this context, Brazil's new role in peacekeeping/peacebuilding operations has been associated with its efforts to reshape its role as a global player (Esteves 2010, 615; Cavalcante 2010, 143; Almeida 2014, 61; Wrobel \& Herz, 2002).

From 1957 to 1999, Brazil deployed over 11,000 troops and more than 300 police personnel on UN missions. But as Kenkel (2010a) notes, "Brazil's contribution consisted of a steady trickle of small teams of military observers, staff officers and liaison officers, with three major exceptions until the advent of MINUSTAH in 2004" (655). Prior to its prominent participation in the UN mission in Haiti in 2004, Brazil persistently rejected taking part in missions authorized under Chapter VII ${ }^{4}$. The exceptions were "battalion-sized contingents sent to the Sinai (UN Emergency Force UNEF, 1956-1967) and Angola (UN Angola Verification Mission - UNAVEM, 19951997), as well as a large police contingent to UN Transitional Administration in East Timor (UNTAET), 1999-2002” (Kenkel 2013a, 279).

Participation in peace operations has been historically associated with Brazil's willingness to be integrated into the global cartography (Wrobel \& Herz 2002, 256; Esteves 2010, 615). Even though "Brazilian positions and attitudes on UN peacekeeping issues" are rather unclear (Cavalcante 2010, 143), Brazilian State policies and agendas concerning international security under Luis Inácio Lula da 
Silva's term of office incorporated concepts and goals that appear to be congruent with the country's ambitions. The 2005 National Defense Policy includes in its guidelines the stipulation that Brazil must "have a capability to project its power in order to participate in peace operations established or authorized by the UN Security Council" (Ministry of Defense, Brazil, 2005, 7.1 - XXIII). The document explicitly states that one of the goals of national defense is "the projection of Brazil in the concert of nations and its greater integration into the international decision-making process" (Ministry of Defense, Brazil, 2005, 5 - VI).

The principles of national sovereignty, non-intervention, and peaceful settlement of disputes have been deeply embedded in Brazil's political and juridical cultures (Serbin and Rodrigues 2011; Almeida 2014, 31). However, the risk of isolation from the international community combined with a renewed desire to participate in international affairs as a powerful player could be indicated as major triggers that led Brazil to reevaluate its commitment to the principles of national sovereignty and nonintervention.

Brazil's decision to take over the United Nations Mission of Stabilization of Haiti (MINUSTAH) in 2004, the United Nations Organization Stabilization Mission in the Democratic Republic of the Congo (MONUSCO) in 2013 and the United Nations Interim Force in Lebanon (UNIFIL) in 2013, have been interpreted as

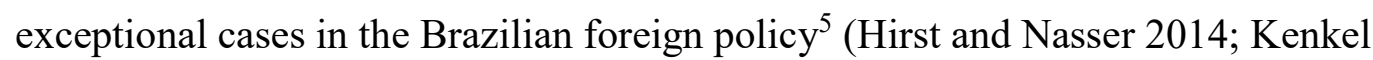
2010b; Moreno et al. 2012). Analyses on the new role of Brazil in international interventions highlight the fact that the need to have its new identity recognized by others has led Brazil to the adaptation of its agenda to pre-given expectations about what a 'strong country' should be and do (De Paula 2018). However, as Hurrell (2006) notes, "one of the difficulties facing potential aspirants to the great power club 
is that the criteria for membership may militate against them" (4). By also assuming an assertive position against the asymmetries of world politics and the hierarchies in decision-making structures of international institutions (see Da Silva 2004a), the country separated itself discursively from the 'great power club'.

Peace operations gave Brazil the stage to demonstrate its commitment to its aspirations and rising ambitions, in particular Brazil's desire to become a more powerful and influential player (Almeida 2014, 32). Nevertheless, the discussion about the principle of non-intervention itself was not faced directly. Instead, Brazil's understanding of intervention was characterized by its focus on tackling 'poverty', 'social injustice', and the promotion of 'equitable development' (Da Silva 2004a, 3). Brazil's involvement in Haiti was not based solely on security concerns. On May 25, 2004, after the adoption of the resolution 1542, in which the UNSC decides to establish the MINUSTAH (UNSC 2004), Lula defined Brazil's new position in a speech at the University of Beijing:

the increasing [political] proximity and consolidation of Brazil's relation to its region require[d] that the situations of instability in countries of the continent [we]re carefully watched by the Brazilian government, oriented by the principle of non-intervention, but also by an attitude of 'non-indifference' (Ministry of Foreign Affairs, Brazil 2007, 19).

At a press conference in Haiti on August 18, 2004, Lula emphasized Brazil's commitment to the promotion of democracy and to the social and economic development of Haiti, which he referred to as a brother country (Da Silva 2004b, my emphasis). A year later, Amorim asserted that Brazil had a "clear understanding that the peace of that sister nation, though at the margins of our continent, require[d] a long-term commitment from the international community" (Amorim 2005, my emphasis). 
The notion of 'non-indifference' was first adopted by the African Union (Hermann 2011, 20; Almeida 2014, 33). The distinction between 'non-indifference' and 'intervention' is in the rhetoric of southern solidarity and a more horizontal political and/or discursive positioning in relation to the 'other'. The new concept was first employed by Brazil in the context of Brazil's participation in MINUSTAH, a mission that was interpreted as an opportunity for the country to demonstrate its new identity as a solidary brother, or sister, but also the kind of responsibilities it was finally willing to assume (Almeida 2014, 34). In the next section, I explore the participation of Brazil in this mission, examining how Brazil's approach to international security could offer news ways of thinking geopolitics.

\section{BRAZIL'S SOLIDARITY IN HAITI AND AT THE UN}

Brazil has contributed to UN missions since 1947, when a multinational team was authorized for the first time by the UN to act in the Balkans. Five Brazilians, military officers and diplomats, participated in this first multinational team. In 1956, the first UN mission with troops, deployed to Suez, included a Brazilian battalion. In the last 71 years, Brazil has participated in a total of $47 \mathrm{UN}$ missions, including 43 peacekeeping operations (Hamann \& Teixeira 2017, 1). As Antonio Patriota (2012[2013]), former Brazilian Minister of Foreign Affairs, emphasizes about Brazil's participation in the UN since 1946, any “opportunity to assist in the shaping of the United Nations diplomatic agenda [...] is especially meaningful for a country like Brazil, for whom the defense and promotion of multilateralism represents one of the structural factors of its external policy" (17-18).

In 2004, for the first time, Brazil had a primary role in a UN mission. Brazilian 
Generals were responsible for the command of troops from a dozen countries, most of them from South America (Almeida 2014, 37). Due to "the very nature of the root causes of Haiti's complex problems" (Braga 2010, 711), MINUSTAH was designed as a model of contemporary multidimensional and integrated operation ${ }^{6}$, characterized by "an intricate institutional arrangement in which military, police and civilian components all fall under the responsibility of a civilian [representative] appointed by the UN Secretary-General (the Special Representative of the Secretary General SRSG)" (Hamann 2009, 40). In order to respond properly to the challenge, the contingent of Brazilian troops has been the largest that the country has ever deployed to peacekeeping operations (Almeida 2014, 37). From 2004 to 2017, Brazil deployed about 37,000 troops to MINUSTAH, distributed in 26 contingents on a rotation basis (Hamann \& Teixeira 2017, 1), led by a total 11 Brazilian force commanders. From 2004 until January 2010, the Brazilian contingents consisted of 1,300 troops. After the earthquake in 2010, and a revision of the mandate, an additional 900 troops were supplied by Brazil, of which a great part consisted of Marine Corps and an engineering company provided by the army to pursue humanitarian tasks (Kenkel 2013b, 348).

MINUSTAH succeed the Multinational Interim Force (MIF), a mission led by the United States and authorized by the UNSC right after the resignation of the Haitian President Jean Bertrand Aristide. MIF was deployed in Haiti in February 2004, and the troops from France, Canada, and United States started leaving immediately after the arrival of the MINUSTAH. Even though the tactics used by the troops from the previous missions had proven to be ineffective for the long-term stabilization of the crisis in $\mathrm{Haiti}^{7}$, when the new mission took over, the United States, France, and Canada disagreed with the approach chosen by the new mission's force 
commanders. According to Braga, an intense pressure for more proactive use of force was received by the Brazilian troops through diplomatic démarches, frequent visits, and diplomatic conversations (Braga 2010,714). He argues that the resistance by South American troops, in particular by Brazilian troops and decision-makers, to a more offensive posture "reflects the culture of Brazilian peacekeepers as conciliators [...] searching for alternative solutions and negotiations and only resorting to force when it is deemed absolutely unavoidable" (Braga 2010, 718).

The Brazilian Ministry of Defense tried to craft a 'Brazilian way' ${ }^{\prime 8}$ to be tested in Haiti (Hirst and Nasser 2014, 2). Moreno et al. (2012) argue that "due to their special interest in the mission, the United States, Canada, and France, managed to have some influence on [the mission's] configuration and mode of action" (385). Despite Brazil's emphasis on the tripod 'security, reconciliation, and development' (Moreno et al. 2012, 386), the pillars of the MINUSTAH mandate reflected a more traditional approach to intra-state conflict. They were: (1) Secure and Stable Environment, (2) Political Process, and (3) Human Rights (UNSC 2004).

Some of the most aggravating challenges to MINUSTAH were related to development. According to the Security Council, "primary development tasks were not to be undertaken by MINUSTAH but rather by donor countries and other international organizations, based on their own interests and capacities" (Braga 2010, 716). Given the gap between a predefined peace operation model and the local reality, the solution was to work through the limitations of the mandate, by establishing a "new set of interactions and arrangements out of the institutional limits of MINUSTAH" (Moreno et al. 2012, 387). Braga suggests that perhaps the most important reason for MINUSTAH's successes have been the "high level of involvement of Brazilian organizations from outside the military ambit" (Braga 2010, 
719), including non-governmental initiatives, such as projects developed by the Brazilian NGO Viva Rio. Moreover, different Brazilian governmental agencies such as the Ministry of Health, the Ministry of Agriculture, and the Brazilian Agency for Cooperation were coordinating efforts in Haiti with Brazil's Foreign and Defense Ministries (Braga 2010, 719-720). The NGO Viva Rio, for instance, carried out sports activities (including capoeira), and cultural initiatives (such as Carnaval celebrations) to strengthen the reconciliation programs it was coordinating in order to help mediate between the Haitian national police and leaderships from different parts of Bel Air, Cité Soleil, and Delmas (Call \& Abdenur 2017, 14). These initiatives are pointed out as some of the ways Brazil "worked to complement the military role of MINUSTAH with initiatives that would promote long-term social well-being and stability" (Call \& Abdenur 2017, 14).

Braga adds that "cultural attributes of Brazilian soldiers and marines were crucial in improving interaction with the local population as well as with Haitian and international authorities" (Braga 2010, 712). As he explains, "the cultural similarity between Haiti and Brazil is far-reaching, ranging from a passion for soccer and carnival to shared religious syncretism. From a Haitian perspective, this identification is very deep" (Braga 2010, 719). One of the MINUSTAH SRSG, Hédi Annabi, who fell victim to the 2010 earthquake, delivered a speech in April 2009 in which he claimed that:

the Brazilian Contingent [...] have made an invaluable contribution to the stabilization process, based on a combination of different qualities: professionalism, firmness and courage in the face of opposition; imagination, sensitivity and a readiness to reach out, whether by playing soccer with a child, providing emergency care, or helping victims of disaster or violence. And, above all, a genuine desire to help the Haitian people, a people with a proud history that has contributed much to the continent, but which now needs the assistance of its friends in the region and of the international community (quoted in Braga 2010, 719). 
This image of the Brazilian military contingent as uniquely sensitive to the needs of others, and able to connect with the Haitian people has been largely accepted and reproduced by different actors involved in the mission as well as by scholars and journalists reporting on Brazil's participation in peacekeeping operations (Dziedzic \& Perito 2008, 1). Despite the acknowledgement of increasing resistance in Haiti against the 'international occupation' and other controversies that plagued the mission (see Lemay-Hébert 2014), there is a widely disseminated perception that Brazilian troops display particular traits that have been praised by the Haitian population (Dziedzic and Perito 2008, 10), but that are not necessarily rewarded in mainstream discourses of international security.

While Brazil's adaptability to Haiti contributed to the positioning of Brazil as a good leader in that particular mission, the dominant interpretation has been that Brazil could only replicate its success in other international missions where it could possibly claim cultural affinity and common historical roots to the host country (Kenkel 2010a, 656-657). By presenting itself as close to Haitians and recognizing in Haiti a reflection of its own problems, Brazil not only challenged the dominant narrative about the boundaries between the sovereign spaces that compose the international order, but it also put itself in a position of vulnerability in relation to the 'other' that is seen as incongruent with the position of authority and responsibility it was aspiring to.

This representation of the Brazilian troops as connected and empathetic has been consistent with another major contribution of Brazilian diplomacy during this period, which was Brazil's proposal at the UN of the concept 'Responsibility while Protecting'. As a manifestation of Brazilian officials' uneasiness with regards to the 
intervention by NATO in Libya ${ }^{9}$, the UN was approached with a suggestion for a new doctrine. The idea behind 'Responsibility while Protecting' is that military action taken in the name of the responsibility to protect must also be carried out in a responsible manner (Österdahl 2013, 460). The new concept does not invalidate the 'RtoP', but it is an invitation for the international community to shift the discussion from when an intervention is necessary and legitimate to how the international community could help in the development of local capacities necessary for the prevention of violations against human rights and the restoration of sovereignty.

In a letter from November 2011, addressed to the Secretary-General and entitled "Responsibility while protecting: elements for the development and promotion of a concept", Brazil's permanent representative to the United Nations, Maria Luiza Ribeiro Viotti (in office from July 25, 2007 to January 16, 2013), discussed Brazil's official understanding and suggestions regarding international interventions and, especially, Brazil's safeguards in relation to the concept of the Responsibility to Protect (R2P). Viotti emphasizes the strict chronological order of the three pillars of the R2P. She states that these three pillars - state sovereignty, international assistance and capacity building, and the responsibility of the international community to take timely and decisive action - "must follow a strict line of political subordination and chronological sequencing. In this sequencing, it is essential to distinguish between collective responsibility, which can be fully exercised through non-coercive measures, and collective security" (Viotti, 2011).

The United States and some European countries have not been very welcoming about the RwP, justifying their dismissive response on the basis that the Brazilian initiative was "an attempt to delay or block interventions that were necessary to prevent mass atrocities" (Almeida 2014, 61). Brazil and other BRICS 
(Russia, India, China, South Africa) countries have been accused of using their global influence in a disruptive way, instead of using it to stop the bloodshed in Syria, for instance, and joining the United States, France and the United Kingdom in their decisions with regards to the reestablishment of stability and maintenance of international peace and security. Susan Rice, former US permanent representative to the United Nations, declared that her country was 'not encouraged' by the performance of India, Brazil and South Africa during their temporary tenure on the Security Council $^{10}$, and she threatened to block their efforts to secure a permanent seat on the Security Council (Gaouette, 2011). India, Brazil and South Africa insisted on diplomatic measures in dealing with oppressive regimes while serving two-year temporary terms on the Security Council. For Susan Rice, this position "might not have [been] anticipated, given that each of them come out of strong and proud democratic traditions" (Gaouette, 2011). However, contrary to Rice's presumption, the three countries have openly expressed their commitment to non-interference and to national sovereignty as guiding principles, even though they have been more flexible than Russia and China regarding proposed civilian protection measures in Syria (Garwood-Gowers 2013, 91).

The new geo-graphing expressed through Brazil's encounter with Haiti and Brazil's proposal of the RwP at the UN subverts the language of victory by challenging the dominant logic of separation and superiority in matters of international security. The agendas and practices of 'powerful' states are usually marked by an interaction with the local population and a representation of the 'local' within a narrative of 'failed state' that assumes hierarchy between 'insiders' and 'outsiders', overlooks the socio-cultural idiosyncrasies of the country, and perpetuates a condition in which 'c'est le blanc qui decide' (it's the white who decides) (Moreno et 
al. 2012, 386). Instead, Brazil has provided an example of a logic that connects, that emphasizes similarities, vulnerabilities, incompleteness, and the fluidity of borders and identities (Gomes 2016, 10). In the concluding section, I explore some challenges to a feminist diplomatic agenda in light of previous empirical and conceptual observations.

\section{THE CHALLENGES TO A FEMINIST DIPLOMATIC DISCOURSE}

The examination of Brazil's participation in the MINUSTAH and the proposal of a new paradigm for international intervention provides a resolution to the limitation identified by Richey in the implementation of the Danish feminist foreign policy. It is complicated for a professed 'feminist' state to position itself as a 'donor' or a superior 'problem-solver' vis-à-vis 'recipients', as this further separates 'undeveloped states' from 'developed states', a process through which 'the problem' is then located in 'undeveloped' territories, and subsequently in 'undeveloped' people's bodies" (Richey 2001, 180). The narratives about the Brazilian leadership of MINUSTAH and its concern with the use of R2P illustrate a singular set of qualities and practices that open up the space for alternative geopolitical imaginaries in which the 'self' and the 'other' are not clearly separated by temporal and spatial boundaries.

However, in its insistence in south-south cooperation and solidarity, and in its resistance to a hierarchical top-down approach to sovereignty, Brazil has not necessarily been taken seriously by those deliberating on the legitimacy of its new identity and on its capacity to assume greater responsibilities as a global player, as the influential presence of France, Canada and the United States on the designing of the MINUSTAH agenda and the pressure against Brazil's resistance to proactive and 
robust use of force in Haiti illustrates. The fact that there might be a contradiction between Brazil's aspirations and the display of qualities that are associated with vulnerability, sensibility and openness towards an 'other' reveals some of the ways the realm of international security is structurally gendered, with institutions, such as the UN, facilitating a certain distribution of power in the international system according to the authority and legitimacy that have been granted or denied to particular gendered subjectivities.

McDonald and Patrick (2010) recommend that "developing countries elevated to positions of authority [...] seriously weigh their responsibilities for global security, abandoning the aspects of G77 and NAM diplomacy that often turn the UNGA into a circus" (19). As in McDonald and Patrick's report on the enlargement of the UNSC, claims for a rearticulation of the international 'order' coming from developing countries are often disregarded as immature and illegitimate. Immaturity and illegitimacy are opposed to rationality and responsibility, terms that are often associated with other overestimated masculine traits such as power, control, and order, which are all expected from those in 'significant' positions in international politics.

As demonstrated in this analysis of Brazil's diplomatic agenda at the beginning of the twenty-first century, some of the obstacles to the making of a world in which solidarity can be ranked as a quality of those who seek recognition, voice and power lie in established conditions of intelligibility through which different identities have been recognized as 'appropriate' in relation to particular positions and roles in the system. In its attempt to redefine its identity and its role in the world, Brazil has had to depend on a number of criteria (for visibility, authority, power, and influence in international institutions) that were beyond its control. 
When we consider the four stages listed by Mesquita and Medeiros (2016) through which a State reshapes its role in the world, it is possible to observe that Brazil has not successfully moved from the third to the fourth stage (where the legitimation process takes place) wherein the recognized qualities displayed by Brazil during its participation in the MINUSTAH, which has been seen as an unprecedented commitment to a foreign intervention in the history of Brazil's foreign policy, have not been translated as appropriate assets of a global player. Thus, Brazil's actions have not been met with the expected feedback from the great powers at the UNSC.

While diplomacy can be defined as an infrastructure for the making of world politics, we should take into account the limitations, derivative of a particular 'masculine' geopolitical order that is continually reproduced, to feminist diplomatic agendas. This is especially pertinent when diplomacy itself has been devalued, in relation to power politics, for being a feminine and weak art (see Kagan 2002). This

paper has demonstrated that feminist diplomatic discourses and practices should find space within a more permissive feminist geopolitics. The translation of feminist agendas into significant and influential status in international politics will require a feminist geopolitical attention to the way the 'pieces' are allowed to move themselves on the globe.

\section{Works Cited:}

Aggestam, K. \& A. Towns. 2018. "The gender turn in diplomacy: a new research agenda." International Feminist Journal of Politics, 1-20 doi:

$10.1080 / 14616742.2018 .1483206$ 
Almeida, P. W. 2014. "Brazilian View of Responsibility to Protect: From 'NonIndifference' To 'Responsibility While Protecting'." Global Responsibility to Protect 6 (1), 29-63. doi: 10.1163/1875984X-00601003

Amorim, C. 2005. "Política externa do governo Lula: os dois primeiros anos." Análise de conjuntura - Observatorio Político Sul-Americano 4, 1-14.

Amorim, C. 2010a. "The Statement by H.E. Ambassador Celso Amorim, Minister of External Relations of the Federative Republic of Brazil, at the General Debate of the 65th Session of the General Assembly of the United Nations." New York: UNGA. Accessed Feb 052018 https://gadebate.un.org/sites/default/files/gastatements/65/BR_en.pdf Amorim, C. 2010b. No novo mapa do mundo, o País está maior. O Estado de S. Paulo. Accessed Feb 052018 http://politica.estadao.com.br/noticias/geral,no-novomapa-do-mundo-o-pais-esta-maior,592193

Amorim, C. 2010c. Amorim, C. (2010c). Let's Hear from the New Kids on the Block. International Herald Tribune-New York Times. Accessed Feb 052018 http://www.nytimes.com/2010/06/15/opinion/15iht-edamorim.html Braga, C. C. V. 2010. "MINUSTAH and the Security Environment in Haiti: Brazil and South American Cooperation in the Field.” International Peacekeeping 17 (5), 711-722. doi: 10.1080/13533312.2010.516979 
Butler, J. 1997. Excitable Speech: A Politics of the Performative. New York:

Routledge.

Cavalcante, F. 2010. "Rendering peacekeeping instrumental? The Brazilian approach to United Nations peacekeeping during Lula da Silva years (2003-2010)." Revista Brasileira de Política Internacional 53 (2), 142-159. doi: 10.1590/S003473292010000200008

Da Silva, L. I. L. 2004a. “The Statement by H.E. Luiz Inácio Lula da Silva, president of the Federative Republic of Brazil, at the General Debate of the 59th Session of the General Assembly of the United Nations.” New York: UNGA. Accessed Sept 12 2008 http://www.un.org/webcast/ga/59/statements/braeng040921.pdf

Da Silva, L. I. L. 2004b. “Statement by H.E. Luiz Inácio Lula da Silva, president of the Federative Republic of Brazil.” Press conference. Porto Príncipe, Haiti. Accessed Aug 292018 http://www.biblioteca.presidencia.gov.br/presidencia/expresidentes/luiz-inacio-lula-da-silva/discursos/1o-mandato/2004/18-08-2004declaracao-a-imprensa-do-presidente-da-republica-luiz-inacio-lula-da-silva-emconjunto-com-o-presidente-do-haiti-boniface-alexandre

Da Silva, L. I. L. 2005. “Discurso do Presidente da República, Luiz Inácio Lula da Silva, na cerimônia de formatura da Turma de 2002 do Programa de Formação e Aperfeiçoamento do Instituto Rio Branco. Brasília, Palácio do Itamaraty.” Accessed Feb 122018 http://www.biblioteca.presidencia.gov.br/presidencia/expresidentes/luiz-inacio-lula-da-silva/discursos/1o-mandato/2005/discurso-do- 
presidente-da-republica-luiz-inacio-lula-da-silva-na-cerimonia-de-formatura-daturma-de-2002-do-programa-de-formacao-e-aperfeicoamento-do-instituto-riobranco/view

De Paula, F. R. 2018. The Emergence of Brazil to the Global Stage: Ascending and Falling in the International Order of Competition. New York: Routledge.

Dixon, Deborah P. 2016. Feminist Geopolitics. New York: Routledge.

Dziedzic, M., \& R. M. Perito. 2008. Haiti: Confronting the Gangs of Port-au-Prince, special report 208, United States Institute of Peace. Washington, DC. Accessed Sept 102017 http://www.usip.org/resources/haiti-confronting-the-gangs-port-au-prince

Dowler, L. \& J. Sharp. 2001. “A Feminist Geopolitics?” Space \& Polity 5 (3), $165-$ 176. doi: $10.1080 / 13562570120104382$

Call, C. T. \& A. E. Abdenur. 2017. “A ‘Brazilian way’? Brazil’s approach to peacebuilding." Geoeconomics and Global Issues, Paper 5, 1-26. Foreign Policy at Brookings. Accessed Jun 122018 https://www.brookings.edu/research/a-brazilianway-brazils-approach-to-peacebuilding/

Chowdhry, G. \& S. Nair. 2002. Introduction: Power in a postcolonial world: race, gender, and class in international relations. In Power, Postcolonialism and International Relations, 1-32. London: Routledge. 
Conway, D. 2008. Contesting the masculine state. In Parpart, J. L. \& M. Zalewski (Eds.) Rethinking the Man Question: Sex, Gender and Violence in International Relations, 127-142. London: Zed Books.

Corrêa, L. F. de S. 2013. Brazil in the United Nations: 1946 - 2011. Brasília: Fundação Alexandre de Gusmão.

Esteves, P. 2010. "Peace Operations and the Government of Humanitarian Spaces." International Peacekeeping 17 (5), 613-628. doi: 10.1080/13533312.2010.516961

Faria, C. A. P. \& C. G. Paradis. 2013. "Humanism and Solidarity in Brazilian Foreign Policy Under Lula (2003-2010): Theory and Practice.” Brazilian Political Science Review 7 (2): 8-36. doi: 10.1590/S1981-38212013000200001

G4. 2012. Ministerial Meeting of the G4 Countries in the margins of the 67th Session of the UNGA, Joint Press Statement, New York. Accessed Aug 082017 http://www.itamaraty.gov.br/index.php?option=com_tags\&view=tag\&id=509-g4brazil-germany-india-and-japan\&lang=pt-BR

Gomes, M. S. 2016. “Analysing interventionism beyond conventional foreign policy rationales: the engagement of Brazil in the United Nations Stabilization Mission in Haiti (MINUSTAH)." Cambridge Review of International Affairs, 1-18. doi: $10.1080 / 09557571.2016 .1230587$

Garwood-Gowers, A. 2013. The BRICS and the responsibility to protect in Lybia and 
Syria. In Maguire, R.; Lewis, B. \& C. Sampford (Eds.) Shifting Global Powers and International Law: Challenges and opportunities, 81-99. New York: Routledge.

Hamann, E. 2009. "United Nations Presence in Haiti: Challenges of a Multidimensional Peacekeeping Mission.” Conflict Trends, (4), 37-45.

Hamann, E. \& C. A. R. Teixeira. 2017. Brazil's participation in MINUSTAH (20042017): perceptions, lessons and practices for future missions. Rio de Janeiro: Igarapé Institute.

Hermann, B. 2011. Soberania, não intervenção e não indiferença: reflexöes sobre o discurso diplomático brasileiro. Brasília: Fundação Alexandre de Gusmão.

Hirst, M. \& R. M. Nasser. 2014. "Brazil's involvement in peacekeeping operations: the new defense-security-foreign policy nexus." Norwegian Peacebuilding Resource Centre (NOREF), September. Accessed September 292017 http://brasilnomundo.org.br/wp-content/uploads/2014/10/Hirst-e-Nasser.pdf Hoffman, J. 2001. Gender and Sovereignty: Feminism, the State and International Relations. New York: Palgrave Macmillan.

Hooper, C. 2001. Manly states: Masculinities, International Relations, and Gender Politics. New York: Columbia University Press.

Hovet, T. 1963. "United Nations Diplomacy.” Journal of International Affairs, 17(1), 
Hurrell, A. 2006. "Hegemony, liberalism and global order: what space for would-be great powers?" International Affairs 82 (1), 1-19. doi: 10.1111/j.14682346.2006.00512

Huthings, K. 2008. Cognitive short cuts. In Parpart, J. L. \& M. Zalewski (Eds.) Rethinking the Man Question: sex, gender and violence in international relations, 2346. London: Zed Books.

Hyndman, J. 2004. "Mind the gap: bridging feminist and political geography through geopolitics.” Political Geography 23 (3) 307-322. doi: 10.1016/j.polgeo.2003.12.014

Hudson, V. M. 2012. The history and evolution of foreign policy analysis. In Smith, S.; Hadfield, A. \& T. Dunne (Eds.) Foreign Policy: Theories, Actors, Cases, 13-34. Oxford: Oxford University Press.

Kagan, R. 2002. "Power and Weakness. Why the US and Europe See the World Differently." Policy Review 113 (June \& July), 3-28.

Kenkel, K. M. 2010a. "Stepping out of the Shadow: South America and Peace Operations.” International Peacekeeping 17 (5), 584-597. doi:

$10.1080 / 13533312.2010 .516928$ 
Kenkel, K. M. 2010b. "South America's Emerging Power: Brazil as Peacekeeper." International Peacekeeping 17 (5), 644-661. doi: 10.1080/13533312.2010.516958

Kenkel, K. M. 2013a. "Brazil's Peacekeeping and Peacebuilding Policies in Africa" Journal of International Peacekeeping 17 (3-4), 272-292. doi: 10.1163/187541121704006

Kenkel, K. M. 2013b. Brazil. In A. J. Bellamy \& P. D. Williams (Eds.). Providing Peacekeepers: The Politics, Challenges, and the Future of United Nations Peacekeeping Contributions. Oxford: Oxford University Press.

Kofman, E. 1996. Feminism, gender relations and geopolitics: problematic closures and opening strategies. In E. Kofman \& G. Youngs (Eds.). Globalization: theory and practice. New York: Pinter.

Koopman, S. 2011. "Alter-geopolitics: Other securities are happening.” Geoforum 42, 274-284. doi: 10.1016/j.geoforum.2011.01.007

Lemay-Hébert, N. 2014. "Resistance in the Time of Cholera: The Limits of Stabilization through Securitization in Haiti.” International Peacekeeping 21 (2), 198213. doi: $10.1080 / 13533312.2014 .910399$

Massey, D. 2005. For Space. London: SAGE Publications.

McDonald, K. C. \& S. M. Patrick. 2010. “UN Security Enlargement and U.S. 
Interests, report 59." International Institutions and Global Governance Program Council on Foreign Relations. December. Accessed Sept 202017 https://www.cfr.org/content/publications/attachments/UNSC_CSR59.pdf

Mesquita, R. \& M. A. Medeiros. 2016. "Legitimising Emerging Power Diplomacy: an Analysis of Government and Media Discourses on Brazilian Foreign Policy under Lula." Contexto Internacional 38 (1), 385-432. doi: 10.1590/S01028529.2016380100011

Ministry of Defense, Brazil. 2005. Política Nacional de Defesa. Brasília: Ministério da Defesa.

Ministry of Foreign Affairs, Brazil. 2007. Repertório de Política Externa. Brasília: Fundação Alexandre de Gusmão.

Moreno, M. F., C. C. V. Braga \& M. S. Gomes. 2012. “Trapped Between Many Worlds: A Post-colonial Perspective on the UN Mission in Haiti (MINUSTAH)." International Peacekeeping 19 (3), 377-392. doi: 10.1080/13533312.2012.696389

Moura, G. 2013. Brazilian Foreign Relations - 1939-1950: the changing nature of Brazil-United States relations during and after the Second World War. Brasília: Fundação Alexandre de Gusmão.

Ó Tuathail, G. 1996. Critical geopolitics. Minneapolis: University of Minnesota. 
Patriota, A. de A. 2013. "Presentation to the Third Edition". In Corrêa, L. F. de S. Brazil in the United Nations: 1946 - 2011. Brasília: Fundação Alexandre de Gusmão.

Pettman, J. J. 1996. Worlding women: a feminist international politics. London, New York: Routledge.

Richey, L. A. 2001. “In Search of Feminist Foreign Policy: Gender, Development, and Danish State Identity." Cooperation and Conflict 36 (2), 177-212. doi: $10.1177 / 001083601400422351$

Sending, O. J., V. Pouliot \& I. B. Neumann. 2015. Diplomacy and the Making of World Politics. Cambridge: Cambridge University Press.

Serbin, A. \& G. M. A. Rodrigues. 2011. "The Relevance of the Responsibility to Protect for Latin America and the Caribbean Region: Prevention and The Role of Civil Society" Global Responsibility to Protect 3 (3), 266-285. doi: $10.1163 / 187598411 X 586025$

Staeheli, L. 2001. "Of Possibilities, Probabilities and Political Geography.” Space and Polity 5 (3), 177-189. doi: doi.org/10.1080/13562570120104391

Staeheli, L., E. Kofman \& L. Peake. 2004. Mapping women, making politics. New York: Routledge.

UNSC. 2004. S/RES/1542. Adopted by the Security Council at its $4961^{\text {st }}$ meeting on 
30 April 2004. Accessed Aug 252018

https://www.securitycouncilreport.org/atf/cf/\%7b65BFCF9B-6D27-4E9C-8CD3-

CF6E4FF96FF9\%7d/CAC\%20SRES\%201542.pdf

Visentini, P. F. 2011. Brazil's Contemporary Foreign Policy: An Affirmative Agenda.

In Hofmeister, W. \& S. Vogt (Eds.) G20 - Perceptions and Perspectives for Global Governance, 31-40. Konrad Adenauer Stiftung.

Weiss, T. 2003. "The illusion of UN Security Council Reform.” The Washington Quarterly 26 (4), 147-161. doi: 10.1162/016366003322387163

Wrobel, P. \& M. Herz. 2002. A Política Brasileira de Segurança no Pós-Guerra Fria. In Brigagão, C. \& C. Proença Jr. (Eds.) Brasil e o Mundo: Novas Visões, 256-318. Rio de Janeiro: Francisco Alves/Fundação Konrad Adenauer.

Williams, J. \& V. Massaro. 2013. "Feminist Geopolitics: Unpacking (In)Security, Animating Social Change.” Geopolitics 18 (4), 751-758. doi:

$10.1080 / 14650045.2013 .816842$

\footnotetext{
${ }^{1}$ BRICS is an association of five states (Brazil, Russia, India, China, South Africa) that have shared the status of emerging economic powers at the beginning of the twenty first century. The IBSA Dialogue Forum was founded in 2003 as a platform for India, Brazil and South Africa to cooperate and promote coordination on global issues. G20 is a bloc of developing nations established on August 20, 2003 in the
} 
context of the negotiations in the $5^{\text {th }}$ Ministerial World Trade Organization conference held in Cancún, Mexico.

${ }^{2}$ From 2003 to 2013, optimistic analyses about Brazil and its economic and political position as an emerging global player still prevailed in magazines, books, scholarly journals, and other venues. In 2013, a political crisis and a shrinking economy started shifting the scenario and the narratives about the country's role in international politics.

${ }^{3}$ The Swedish Foreign Service action plan for feminist foreign policy 2015-2018 including focus areas for 2017 is available at: http://www.government.se/4990fa/contentassets/bca76b4547ad46fb929ece47e 7cfe26 d/swedish-foreign-service-action-plan-for-feminist-foreign-policy-2015-2018including-focus-areas-for-2017.pdf Canada's Feminist International Assistance Policy is available at http://international.gc.ca/world-monde/issues_developmentenjeux_developpement/priorities-priorites/policy-politique.aspx?lang=eng

${ }^{4}$ Article 42 of Chapter VII of the United Nations Charter authorizes the UN Security Council to take action by air, sea, or land forces in order to maintain or restore international peace and security, when measures provided for in Article 41, such as economic sanctions, prove to be inadequate. Chapter VII of the UN Charter is available at http://www.un.org/en/sections/un-charter/chapter-vii/

${ }^{5}$ Even though UNIFIL and MONUSCO have also been considered peculiar cases in the history of Brazil's contribution to UN missions, this paper focuses on the role of 
MINUSTAH to the country's diplomatic agenda. MINUSTAH is considered the most significant peacekeeping commitment to date, in number of troops deployed by the country and Brazilian force commanders in charge during the mission. A comparative of Brazil's contribution to UN peacekeeping operations is available at: http://www.providingforpeacekeeping.org/2014/04/03/contributor-profile-brazil/

${ }^{6}$ Multidimentional operations prioritize the protection of civilians in UNCS mandates as well as the conditions for post-conflict reconstruction of political, economic and civil institutions. The elements of a multidimensional operation started to be included in UNSC mandates after the publication of the Brahimi Report (2000).

${ }^{7}$ Since the military coup that overthrew the government of Jean-Bertrand Aristide (first popularly elected president in Haitian history) on September 30, 1991, the international community has been unsuccessfully calling for the restoration of democracy and sustainable peace in the country. On July 31, 1994, UNSC passed resolution 940, the first one authorizing the use of force to restore democracy in a member nation. The intervention was known as Operation Uphold Democracy. Many Latin American countries, including Brazil, opposed the resolution.

${ }^{8}$ The 'Brazilian way' is probably not unique. What I aim to highlight is the emphasis in the literature and official statements on this particular self-representation of Brazil as capable of a more horizontal kind of interaction. The passion for football (soccer), shared African roots, and the historical and geographical connections between Brazil and Haiti have all been discursively used as way to legitimize and justify the presence 
of Brazilian soldiers in Haiti as brothers who were there extending a hand, instead of a disciplining father.

${ }^{9}$ The resolution 1973 (2011) was adopted by a vote of 10 in favor and 5 abstentions (Brazil, China, Germany, India, and Russian Federation). The UNSC authorized member states, “acting nationally or through regional organizations or arrangements, to take all necessary measures $[\ldots]$ to protect civilians and civilian populated areas under threat of attack in the Libyan Arab Jamahiriya, including Benghazi, while excluding a foreign occupation force of any form on any part of Libyan territory [...]". The resolution is available at: https://www.un.org/press/en/2011/sc10200.doc.htm\#Resolution

${ }^{10}$ Brazil was a non-permanent member from 2010 to 2011. South Africa and India were in this same position from 2011 to 2012. 